FACTA UNIVERSITATIS

Series: Economics and Organization Vol. 16, No 2, 2019, pp. 129 - 144

https://doi.org/10.22190/FUEO19021290

Original Scientific Paper

\title{
UNDERWRITING PERFORMANCE SHOCKS IN THE NON-LIFE NIGERIAN INSURANCE INDUSTRY AND MACROECONOMIC RISKS: A VECTOR AUTO REGRESSIVE APPROACH
}

\author{
$U D C 368.03(662.2)$
}

\author{
Akinwunmi Kunle Onafalujo \\ Lagos State University, Department of Insurance, Lagos State, Nigeria
}

\begin{abstract}
Insurance company's performance can be stymied by internal and external risks. Industry reports show 23 companies out of the 55 operating companies (about 42\%) in Nigeria recorded net operating losses in 2015. Macroeconomic risks are external and may be quite significant in providing an (un)favourable environment for performance of the industry particularly in a developing economy like Nigeria. Reflecting on the contribution of insurance to the Nigerian economy which shows an abysmally low penetration, averaging below one percent of GDP when compared to African peers such as South Africa at $13 \%$ and Kenya above two percent; it is of essence to investigate how these risks affect its performance which by implication could adversely affect insurance penetration. Dynamic least square regression technique was employed to study the dynamics of macroeconomic risks (GDP, inflation rate, and interest rate) on underwriting performance over the period 1981-2015. Weighed against theoretical underpinnings and other studies particularly in western economies, the study has evidence that interest and inflation rate shock adversely underwriting performance. Also, real GDP does not have positive shock on premium growth and loss ratio. Monetary policy should address inflation, and interest rates if the underwriting performance shocks in the non-life sector are to be mitigated in Nigeria. In the long term, government should focus on how to improve income per capita and reduce income inequality and dependency ratio so as to connect insurance consumption to real GDP growth.
\end{abstract}

Key words: Macroeconomic risks, Underwriting Performance shocks, profitability

JEL Classification: E44, G22

Received September 10, 2018 / Revised March 22, 2019 / Accepted April 15, 2019

Corresponding author: Akinwunmi Kunle Onafalujo

Lagos State University, Department of Insurance, Lagos, Nigeria

E-mail: onafalujo@yahoo.com

๑ 2019 by University of Niš, Serbia | Creative Commons Licence: CC BY-NC-ND 


\section{INTRODUCTION}

Financial performance of insurance companies is difficult to understand in view of the provisions for solvency and intangible nature of the output (Berger, Cummins \& Weiss, 1997). These difficulties are predicated on their performance being stymied significantly by competition, internal and external risks (Ayele, 2012). The internal risks are company's specific factors and external riss are macroeconomic factors. The importance of macroeconomic risks is rooted in strategic financial management reasoning which attributes their factors as the leading indicators for setting business strategies because it affects all industries but in different ways (Brigham \& Ehrhardt, 2014). This can be reflected in underwriting shocks which may have arisen from consumption shocks that make the series of performance to be non-stationary at level (Lee, Hsu \& Lee, 2010).

Market failure can thus be precipitated in a turbulent economy. Nigeria's economy is ranked as one of the most volatile in the 1960-2000 periods (World Bank, 2003). In 2015, industry reports show 23 companies out of the 55 operating companies (about $42 \%$ ) in Nigeria recorded losses (Nweke, 2017). However, on aggregate underwriting premium had grown from N234.1 million in 1981 to 187.4 billion in 2013 (Nigeria Insurance Association, (NIA), 2011; 2013; 2015 and CBN statistical bulletin, 2015). The non-life sector also known as general insurance contributed more to insurance penetration in Nigeria in terms of the volume of business done. It accounted for $82.4 \%$ in 2004 moving up to $84.3 \%$ in 2007 but precipitously declining from 2008 after the insurance and pension reforms to $69.98 \%$ in 2013 (NIA, 2014). Since, Nigeria has been described as an attractive business destination, it is therefore important for the insurance industry which according to; Outreville, 1990; Ward \& Zurbruegg, 2000; Brainard, \& Schwartz, 2008; Outreville 2013, contributes significantly to economic growth vide financial intermediation and strengthening of risk taking ability (Charumathi, 2012) to understand underwriting or consumption shocks.

From micro-economic theory, profitability of an industry influences growth through competitive models (Pervan, Arneric \& Curak, 2013). Also, intense competition can influence performance negatively (Chidambaran, Pugel \& Saunders, 1997; Kaplan \& Celik, 2008; Goddard, Liu, Molyneux \& Wilson, 2011). Whittington (1980) cited in Hardwick \& Adams (2002) stated that "higher profits provides the means (greater availability of finance through retained profits or capital market) and the incentive (a high rate of return) from investments." Lee (2014) buttressed this opinion on the persuasion that stakeholders' interests are stimulated on perceived profitability; or in other economic measures like pricing (Chidambaran, Pugel \& Saunders, 1997). Insurance business competes by growing premiums (Kozak, 2011); and reducing loss propensity while ensuring asset growth through investment activities (Shiu, 2004). These activities could receive shocks from macroeconomic risks such as inflation and interest rates, and changes in GDP (Pervan \& Pavic, 2010; Kozak, 2011). Thus, in conformance to the foregoing, performance shocks in the industry arising from macroeconomic risks must be understood, particularly in a turbulent economy like Nigeria. In Figure one, 1981-2013, claims were almost stable; premium grew slowly and moved more rapidly following recapitalization in 2005; but asset growth was rather explosive significantly after the recapitalization, but then what was the role of macroeconomics risks. 


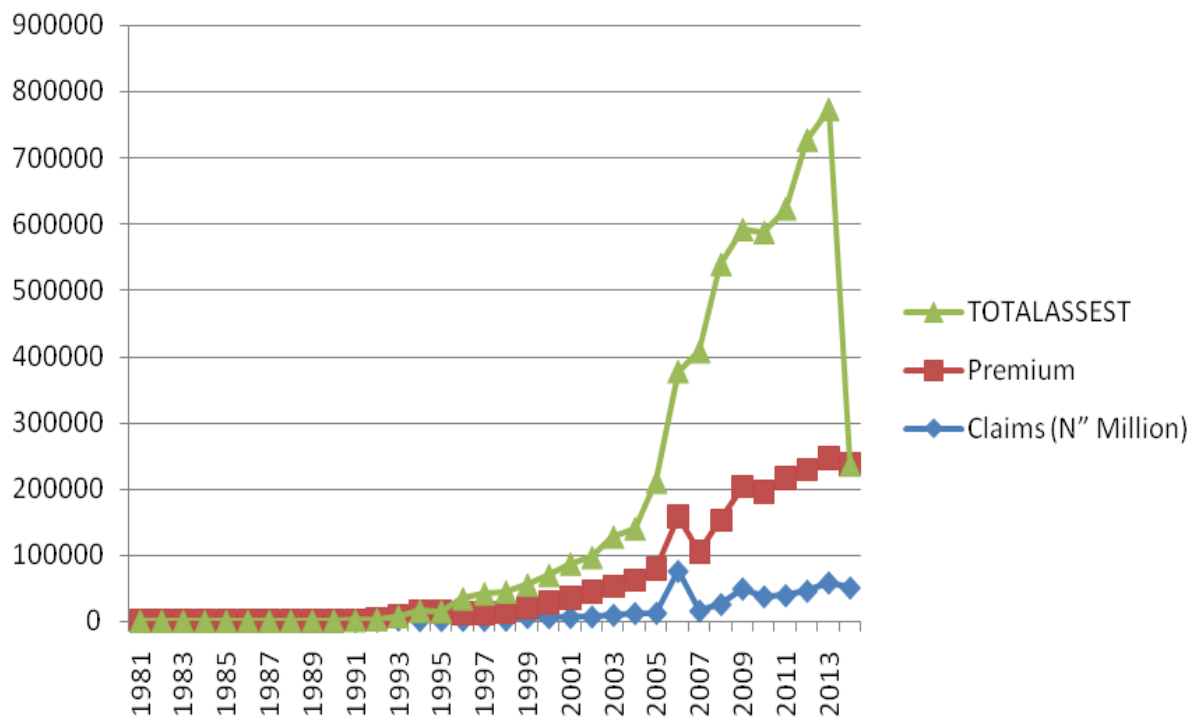

Fig. 1 Trend graph of claims, premium and total assest 1981-2014 of the Nigeria Insurance Industry obtained from CBN statistical bulletin (2015) Source: Author's Graphical Estimation

While many previous studies had focused on profitability and performance in manufacturing (see Ito \& Fukao, 2010; Seelanatha, 2011) and banking mainly in advance economies (Williams, 2003; Athanasoglous Brissimis,\& Delis. 2008; Vejzagic $\&$ Zarafat, 2014), there were few emerging studies on the structure of performance in the insurance sector. Most of the researchers combined internal and external factors in their works but this paper adds to deeper understanding of performance shocks of double digit inflation rate, high interest rate with different exchange rate regimes in a fast growing African economy. The study hypothesizes that macroeconomic risks significantly introduce shocks to the underwriting performance of non-life Nigerian insurers measured by growth of premiums and loss ratio. Understanding how macroeconomic risks affect performance in a turbulent economy will improve the knowledge base of investors and policy makers and reduce the fears of policyholders about the industry and in particular the existence of possible underwriting cycles (Doherty \& Garven, 1995).

\section{CONCEPTUAL FRAMEWORK AND EMPIRICAL LITERATURE}

The understanding of external risks' (referred to as environmental factors in strategic management) influence on industries is important in strategic financial management because they provide the leading indicators for setting business strategies (Levy, 2002; Brigham \& Ehrhardt, 2014). Indeed, business cycles can be initiated by macroeconomic risks (inflation, interest and GDP growth rates) and a whole industry may experience performance shocks precedent to it (Weiss, 2007). Shocks are major underwriting losses or gains in underwriting performance (Shuford, 2004). The way it affects insurance 
industry reflects in swings in losses or premium growth (underwriting performance indicators) (Doherty \& Garven, 1995); and had formed a pigeon which has piqued insurance researchers (Weiss, 2007). In recent times, the interest of researchers has been more tuned to the insurance sector as the role of insurance expands within the economic space and the claim that it is less exposed to systemic risk when compared with banks (Baluch, Mutenga \& Parsons, 2011). Extensive studies have also been carried out on determinants of profitability as a financial performance in the insurance sector but more on internal than external factors. The studies on the link with macroeconomic factors focused more on causal relationship between economic growth and insurance development (Ward \& Zurbruegg, 2000; Brainard, 2008; Han, Li, Moshirian \& Tian, 2010); Chang \& Lee, 2012; Outreville 2012); with lesser attention to how external factors affect performance or profitability of insurers.

The researches on the relationship between profitability and firm specific factors both in the life and non-life sectors had mixed outcomes. In Pakistan and India, an inverse relationship between loss ratio and profitability was detected (Malik, 2011). Choi (2010) in US confirmed size, leverage, reinsurance and liquidity are relevant to profitability.

The others investigated both firm specific factors and macroeconomic variables in a single model with no clear definitive findings. Cheng and Huang (2001) cited in Lee (2014) established the existence of relationship between macroeconomic factors performance of insurers. Shiu (2004) did a panel analysis on the UK non-life companies 1986-1999 and found liquidity, underwriting profits, unexpected inflation and interest rate were significant determinants of performance. Similarly, Curak, Pepur, and Poposki, (2011) investigated determinants of profitability of composite companies in Croatia in a six-year period and reported that size, underwriting profit, inflation and equity returns were significant to return on equity. Datu (2016) in the Philippines found a negative relationship between inflation and profitability. Suffice to say that there were lesser investigations strictly looking at how macroeconomic factors affect profitability in the non-life insurance sector.

Performance had been measured more in the studies as discussed earlier by return on assets or return on equity as indicators of profitability (Cheng and Huang (2001) cited in Lee, 2014; Datu, 2016). In Kohers and Greene (1977), performance was measured by risk-adjusted return. Along the same line Fairley (1979); Cummins (1991) determined performance from underwriting return which combined premium and loss expenses.

Although, studies carried out in these advanced economies also suggested the existence of underwriting cycles during which cash-flow underwriting occurs to stabilize underwriting shocks (Weiss, 2007). These findings give some insights that research is necessary to understand the extent to which macroeconomic factors constitute risks or shocks to underwriting performance. This is crucial to the Nigerian turbulent economic environment where insurance penetration is one of the worst in the world. Researches on the Nigerian frontier were fixated on single variables relationship with profitability and only tangential to underwriting performance. The few studies on insurance profitability were by Agiobenebo and Ezirim (2002) who investigated the impact of financial intermediation on profitability of insurance companies in Nigeria and established a positive link; Ahmed (2016) also found that size influences the profitability of Nigerian insurers. This study fills the gap in the investigation of performance in the insurance industry related to premium growth and changes in losses that could arise from external shocks. 


\subsection{Theoretical Framing of Performance in the Non -Life Sector and Macroeconomic Risks}

Theoretically, Fischer's 1971 seminal model links nominal interest to be a function of expected inflation rate. Implying inflation and interest rate changes should impact economic functions in the same direction. The relationship of inflation and interest rates to performance is indicated in the theoretical estimation of insurance premium. This is computed from discounted losses plus expenses and profit (referred to as risk charge) functionally expressed in (Doherty \& Garven, 1995; Weiss 2007) as:

$$
\frac{E l\left(I_{c,} I\right)+\operatorname{Expenses}\left(T_{t}\right)+\operatorname{Pr} \text { ofit }}{1+r}
$$

Where $\mathrm{P}$ is premium, EL is expected losses, $\mathrm{I}_{\mathrm{c}}$ is claims inflation, $\mathrm{I}$ is expected inflation, $r$ is interest rate and $T_{t}$ is the technology. The model reveals the fundamental principle of insurance operations (Tosetti, Behar, Fromenteau \& Menart (2001) and also shows the relationship between premium, expected losses, interest rate, inflation and profitability for the insurance business model. Based on this insurance concept, pricing of premium is positively related to inflation and inversely related to interest rate. This is also demonstrated by Fairley (1979) in the Capital Asset Pricing Model for insurance where underwriting return or premium was shown to have inverse relationship to interest rate (see Cummins, 1991 for financial models on insurance). But in a rate- tariff non-life insurance regime like Nigeria, discounting is irrelevant; and the behavior of customers to both variables might be unclear (Shiu, 2004).

\section{Interest Rate Risk}

Interest rate risk occurs due to changes in the interest rate (Shiu, 2004). The interest rate impacts the non-life sector in three ways: first, it affects the abilities of insurance companies to undertake cash flow underwriting as postulated in underwriting cycle theory. This suggests mixed outcomes, such that when interest rates are high, insurance companies undercut prices which gradually may result in higher risk taking and consequently result in higher loss ratios. Secondly, it correlates positively with the level of investment yield (Wen \& Born, 2005); using increased investment income to subsidize underwriting (D'Arcy, 1988; Wen \& Born, 2005; Weiss, 2007) can in the opposite direction result in increased premium and hence lower loss ratios. Thirdly, given the timing difference differential between the receipt of premium and payment of claims, a positive relationship is expected between interest rate and loss ratios as well as premium growth rate (Myers \& Cohn, 1987; Cummins, 1991). Shiu (2004) discussed this relationship in terms of duration of assets and liabilities producing different outcomes on performance of insurance companies. Altogether, the underwriting and investment strategies might determine how interest rate impacts loss ratios- that is, losses might increase at a faster rate than premiums or otherwise. Thus the shocks to underwriting performance of insurers from interest is not clearly defined but needs investigation and seems specific to each business environment (Shiu, 2004). 


\section{Inflation Risk}

The theoretical foundation of inflation is on the occurrence of 'rise in the general level of prices' accompanied by dire consequences such as decline in purchasing power (Algrim and D'Arcy, 2012). Since Fisher's (1971) theory predicts a positive relationship between nominal interest rate and inflation rate, it is expected that average investment yield of insurance companies will increase in a double digit inflation like Nigeria. However, inflation has another but countervailing influence in insurance business because losses depend on how much influence it has on claims amount inflation and its frequency (Shiu, 2004); and on the other hand consumption of insurance (Ma \&Pope, 2003). The aggregate effect will depend on how much cash-flow underwriting is used to improve consumption of insurance due to drop in purchasing power. Several studies also found an inverse relationship between inflation and performance (Pervan \& Pavic, 2010).

\section{Gross Domestic Product (GDP)}

Premium growth implies a continuous increase in demand for insurance and positive performance of the insurance industry (Outreville, 1990; 2012). Shocks are fluctuations that are adverse to the profitability/performance and indeed ability to innovate underwriting strategies (Bates \& Atkins, 2007). Previous researches on demand for insurance have consistently established theoretically that a growing economy will boost insurance demand (Outreville, 1990; Brown, Chung \& Frees, 2000; Ma \& Pope, 2003; Liedtke, 2007; Outreville, 2012). On this premise, positive changes in GDP are expected to have positive shocks that are stable in the long run on performance of insurance companies, and vice visa (Pervan \& Pavic, 2010). As earlier said, previous researches were more oriented towards examining the influence of insurance on economy but have theoretically also implied that a growing economy will boost insurance demand. Implicitly, the relationship with loss ratios depends on underwriting strategy but is expectedly inverse and positive for premium growth.

\section{MATERIALS AND METHODS}

Annual data on claims, gross premium, inflation rate, interest rate and GDP was obtained from $\mathrm{CBN}$ statistical bulletin $(\mathrm{CBN}, 2015)$. Additional data on insurance industry 2011-2014 was obtained from Nigeria Insurance Association (2015). Specifically, the model followed Jawadi, Bruneau \& Sghaier, (2009), who used the annual data of five most developed insurance markets: the UK, the USA, Canada, Japan and France for non-linear cointegration study between premiums and financial markets in different years. Since the study investigated performance shocks, VAR was considered an efficient technique in line with previous studies on volatility.

\section{Model Specification}

This study follows the methodological approach of Chen and Hamwi (2000), however with distinct modification. Given that $\mathrm{y}$ is a column vector, which includes premium growth rate, loss ratio (claims divided by premium), inflation, interest rate, and GDP growth rate. If all these variables are I (1), I defines the following stationary Vector Autoregressive VAR (1) specifications. 


$$
y_{t}=\operatorname{lor}_{t}, \text { int }_{t}, \text { inf }_{t}, g d p_{t}
$$

Or

$$
\begin{gathered}
y_{t}=p g r_{t}, \text { int }_{t}, \text { inf }_{t}, g d p_{t} \\
y_{t}=\theta(L) z_{t} ; z_{t} \sim V W N\left(0, \sum_{t}\right.
\end{gathered}
$$

For equation three to be stable, $\theta(L)=1-\theta_{1} L<1$ That is, the sum of all the roots in the VAR polynomial are in absolute term less than 1 . If the system is stable, we can calculate the response of each of the variables included in $y$ to the structural shocks as follows.

Restate equation 3 as

$$
y_{t}=\left(\frac{1}{1-\theta_{1}(L)}\right) Z_{t}
$$

Extend equation 4 to an infinitely moving average of the following form.

$$
\mathrm{y}_{\mathrm{t}}=\theta(L)^{0} Z_{t}+\theta(L)^{1} Z_{t-1}+\theta(L)^{2} Z_{t-2}
$$

Re-represent equation 5 to have

$$
\mathrm{y}_{\mathrm{t}}=Z_{t}+\theta Z_{t-1}+\theta^{2} Z_{t-2}
$$

State a reduced form of equation 7 as

$$
\begin{gathered}
\mathrm{Ay}_{\mathrm{t}}=Z_{t} \\
\mathrm{y}_{\mathrm{t}}=A^{-1} Z_{t}
\end{gathered}
$$

Let $B=A^{-1}$ to have

$$
\mathrm{y}_{\mathrm{t}}=B z_{t}+\theta B z_{t-1}+\theta^{2} B z_{t-2}(10)
$$

To compute the response of each of the variables included in $y$ is to differentiate equation 9 each successive time horizon $(j=0,1,2 \ldots)$. That is:

$$
\begin{gathered}
\frac{\partial \mathbf{y}_{\mathrm{t}+\mathrm{j}}}{\partial \mathbf{z}_{\mathrm{t}}}=\theta^{j} B \\
\frac{\partial \mathbf{y}_{\mathrm{t}}}{\partial \mathrm{z}_{\mathrm{t}}}=B \text { in period zero }
\end{gathered}
$$

In period one ahead

$$
\frac{\partial \mathrm{y}_{\mathrm{t}+1}}{\partial \mathrm{z}_{\mathrm{t}}}=\theta B
$$

In period two ahead

$$
\frac{\partial \mathbf{y}_{\mathrm{t}+2}}{\partial \mathbf{z}_{\mathrm{t}}}=\theta^{2} B
$$

It continues until it gets to the last period of the horizon. Note that if the system is stable, the shocks would disappear and become zero. 


\section{RESULTS}

Prior to estimation, I attempted to check the level of integration using break point unit root test under Augmented Dickey Fuller (ADF) method. Noting the presence of trend, I de-trended by taking the log of each series of interest. Table one reports the unit root test results on loss ratio (LLR), premium growth rate (LPMR), economic growth rate (LGR), inflation (LINF), and interest (LINTR). Stationarity tests were conducted on the transformed data.

Table 1 Unit Root Test Results

\begin{tabular}{lccc}
\hline Descriptor & ADF-Stat & 5\% Critical Value & P-Value \\
\hline LINF & -5.77 & -4.44 & $<0.01$ \\
LGR & -4.88 & -4.44 & 0.01 \\
LINTR & -5.08 & -4.44 & $<0.01$ \\
LLR & -6.22 & -4.44 & $<0.01$ \\
LPMR & -6.04 & -4.44 & $<0.01$ \\
\hline
\end{tabular}

Source: Author's Summarization from E-view Window 10

The ADF statistics in absolute terms appear asymptotically larger than the critical value at 5 percent, and all the corresponding $\mathrm{p}$ values are very small, approximately less than 1 percent. In this context, the null of a unit root exhibiting the variables is refuted. By implication, all the variables of interest are $\mathrm{I}(0)$ and employing a VAR technique is appropriate. Thus, tables 2 and 3 give the estimated results. However, while table 2 is based on the relation between loss ratio and selected macroeconomic variables, table 3 is on the relation between premium growth rate and macroeconomic factors.

Table 2 Loss Ratio-Macroeconomic Variable Relation in Vector Autoregressive Exogenous (VARX) Framework

\begin{tabular}{lccrc}
\hline Regressor & Coefficient & Std Error & \multicolumn{1}{c}{ T-value } & P-value \\
\hline LLR(1) & -0.448746 & 0.198386 & -2.261986 & 0.0266 \\
LLR(2) & -0.167022 & 0.174765 & -0.955695 & 0.3423 \\
LLR(3) & -0.025823 & 0.176156 & -0.146594 & 0.8838 \\
LGR(1) & 0.003389 & 0.076294 & 0.044426 & 0.9647 \\
LGR(2) & 0.148393 & 0.071423 & 2.077652 & 0.0411 \\
LGR(3) & 0.117209 & 0.079814 & 1.468527 & 0.1461 \\
LINF(1) & -0.078751 & 0.127373 & -0.618272 & 0.5382 \\
LINF(2) & 0.001926 & 0.127094 & 0.015155 & 0.9879 \\
LLNF(3) & -0.185062 & 0.118014 & -1.568139 & 0.1210 \\
LINTR(1) & -0.183392 & 0.384732 & -0.476674 & 0.6350 \\
LINTR(2) & -0.312161 & 0.397127 & -0.786047 & 0.4343 \\
LINTR(3) & -0.113307 & 0.368815 & -0.307220 & 0.7595 \\
LPMR & 1.841904 & 0.901517 & 2.043116 & 0.0445 \\
\hline
\end{tabular}

Source: Author's Summarization from E-view Window 10 
The results in table 2 are highly sublime with four findings. Firstly, premium growth rate is significantly positively related to loss ratio. To be precise, a 1 percent increase in premium growth rate increases loss ratio by 1.84 units, implying that loss is increasing at a slower rate as premium increases. Secondly, economic growth rate at different lags influences loss ratio positively particularly at lag two. Conversely and thirdly, historical loss ratios are negatively related to current loss ratio and also, fourthly inflation and interest rate are inverse determinants of loss ratio except in lag 2 . The study established here that an increase in interest rate and inflation induces a decline in loss ratio. That is, premium increases at a faster rate than claims; at any time inflation and interest rates rise or claim rarely increases while premium grows particularly if there is cash-flow underwriting. However, it can be deduced from the first and second findings that due to the differential time between premium and claim payment; claims inflation may later rise and outpace premium growth

Table 3-Premium Growth Rate-Macroeconomic Variable Relation in VARX Framework

\begin{tabular}{lrrrr}
\hline Regressor & Coefficient & Std Error & \multicolumn{1}{c}{ T-value } & P-value \\
\hline LPMR(1) & 0.446809 & 0.220572 & 2.025701 & 0.0463 \\
LPMR(2) & 0.157281 & 0.225426 & 0.697707 & 0.4875 \\
LPMR(3) & 0.037354 & 0.222799 & 0.167662 & 0.8673 \\
LGR(1) & -0.004232 & 0.015079 & -0.28036 & 0.7838 \\
LGR(2) & 0.010742 & 0.018147 & 0.591955 & 0.5556 \\
LGR(3) & -0.011871 & 0.014638 & -0.810925 & 0.4204 \\
LINF(1) & -0.002635 & 0.025214 & -0.104334 & 0.9172 \\
LINF(2) & -0.023127 & 0.025208 & -0.917270 & 0.3619 \\
LLNF(3) & 0.020945 & 0.024184 & 0.866094 & 0.3892 \\
LINTR(1) & 0.008411 & 0.076949 & 0.109312 & 0.9132 \\
LINTR(2) & -0.019963 & 0.081085 & -0.246133 & 0.8062 \\
LINTR(3) & -0.006831 & 0.071822 & -0.095092 & 0.9245 \\
LLR & 0.068373 & 0.042031 & 1.626633 & 0.1081 \\
\hline
\end{tabular}

Source: Author's Summarization from E-view Window 10

It is structurally important to find that premium growth rate has positive impact on loss ratio, just as loss ratio influences premium growth rate positively; that is, underwriting performance is consistently making losses grow at faster pace than premium. It is also discovered that previous premium growth rates are negatively connected to current growth rate of premium. With exemption to lag 2 in the case of GDP growth rate, lags 3 and 1 negatively influence premium growth rate. Inflation rate adversely affects premium growth rate while interest rate also negatively influences premium growth rate at lags 2 and 3; although they are not significant. This simply means that there is sufficient evidence to support that macroeconomic factors in Nigeria are risks or shocks to premium growth rate and indeed underwriting performance of the insurance industry. This adds another theoretical concept that premium will not grow at the same rate with economic growth and could even be inverse. Now the central issues are to address how loss ratio and premium growth rate individually respond to the shocks of the macroeconomic variables. The impulse response function graph is drafted to explain this issue; the graphs are presented in figures 2 and 3. 
Response to Cholesky One S.D. (d.f. adjusted) Innovations Response of LLR to LLR
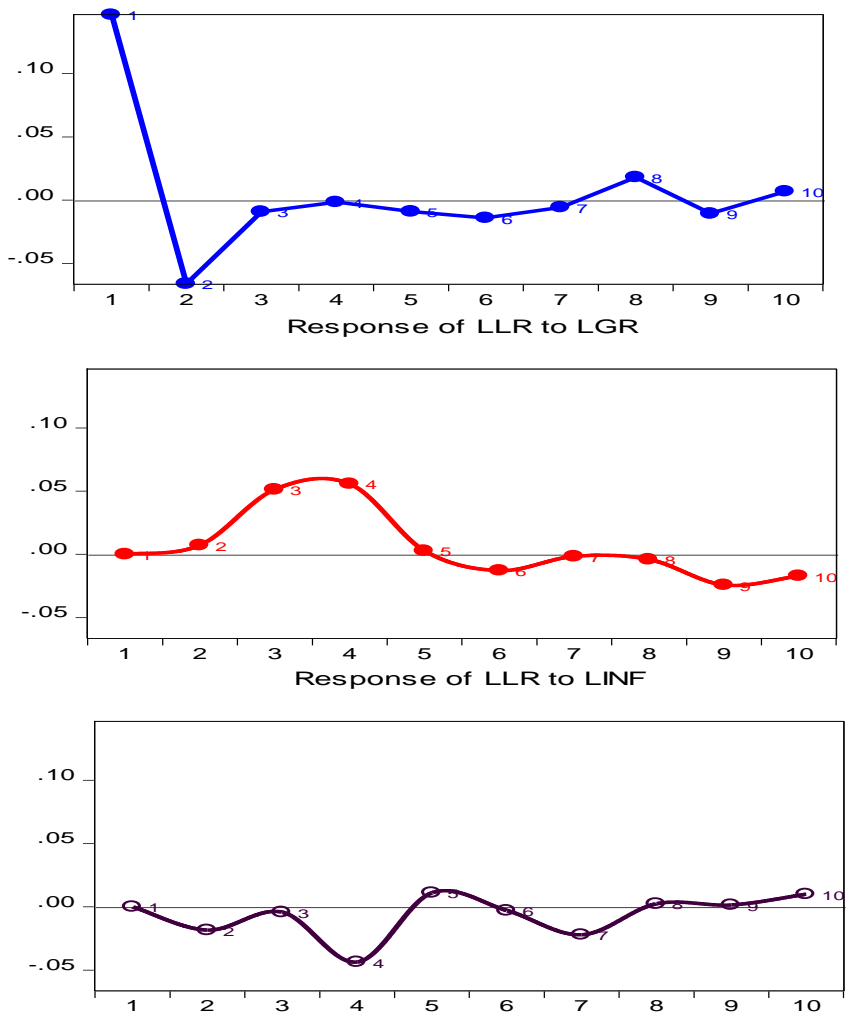

Response of LLR to LINTR

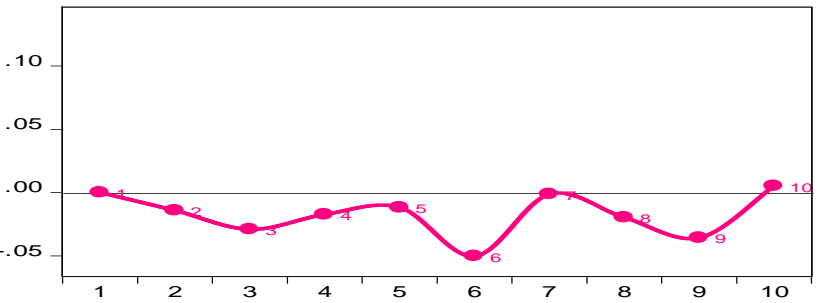

Fig. 2 Response of Loss Ratio to Macroeconomic Shocks Source: Author's Assessment

From figure two, the response of loss ratio to its own shocks is initially very high; it declines immediately, and rises again. However, it does not prolong for a long time. Hence, loss ratio does not respond to its shocks for a long period before coming to rest. The response of loss ratio to the shocks of GDP growth rate rises in the short run and falls in the long run to the negative region. There are few cases it comes to rest; but it however continues to infinity. The response of loss ratio to inflation initially falls into the negative 
region, dwindling over time, and then prolong but rarely getting into the positive region perpetually. In addition, the response of loss ratio to interest rate falls initially into negative, but it does not persist for a long time. Implicitly, loss ratio responds negatively to shocks from inflation and interest rate. But GDP growth shows short run positive shock to loss ratio. This corroborates the findings under the VARX framework.

\section{Response to Cholesky One S.D. (d.f. adjusted) Innovations} Response of LPMR to LPMR
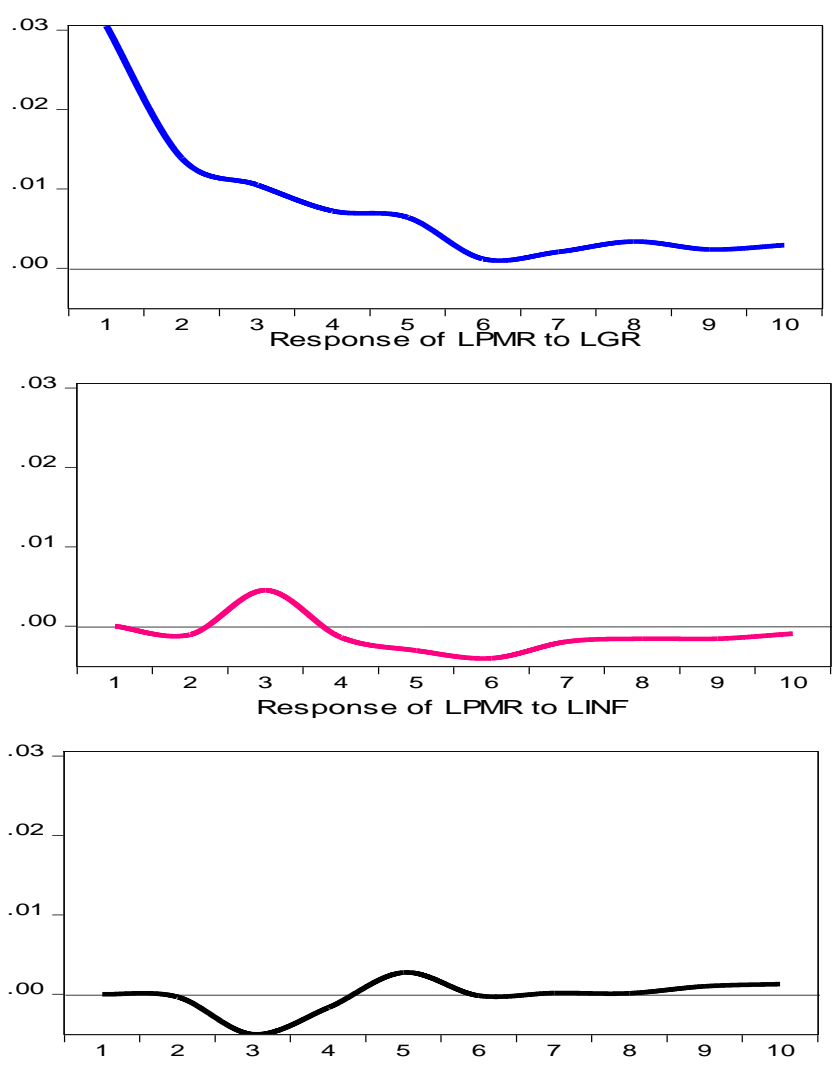

Response of LPMR to LINTR

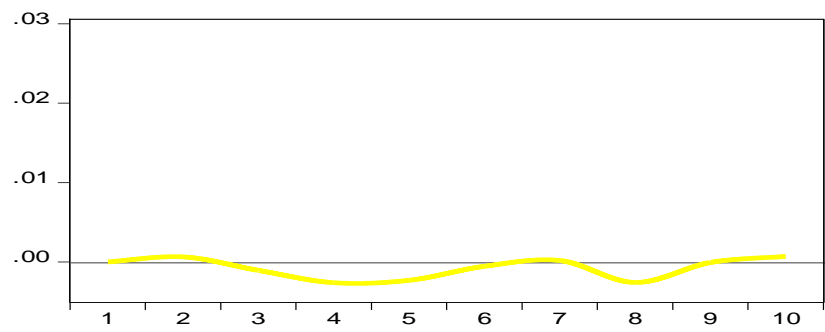

Fig. 3 Response of Premium Growth Rate to Macroeconomic Shocks Source: Authors Estimation 
As shown in figure 3 above, the response of premium growth rate to its shocks rises at first but falls immediately after. In fact, it falls persistently over time without coming to rest. For the shocks of economic growth rate, premium growth rate initially had negative response, and after a while it became positive, later it becomes negative again, and prolongs perpetually. So also, the response of premium growth rate was negative to the shocks of inflation continues indefinitely. This means premium growth rate responded to the shocks or changes in inflation for a long time negatively. Indeed, the response does not come to rest. To the contrary, the response of premium growth rate to the shocks of interest rate fails to persist for a long time, because it comes to rest abruptly. Therefore, premium growth rate responds to interest rate shocks for a short time.

\section{CONCLUSION AND RECOMMENDATIONS}

The empirical literature reviewed showed mixed results on the relationship between premium growth rate and loss ratio as underwriting performance indicators and macroeconomic factors. In Jawadi, Bruneau \& Sghaier, (2009), only the French insurance industry had strong linkage between interest rate and premium growth, the US industry showed mean reversion between the two variables while in Japan, they only had significance with stock market returns. This was explained by the regulations and habits of the insurers in investment practices. For this study, loss ratio and premium growth rates are used as underwriting performance variables. It is interesting to find out that inflation and interest rates are negatively related to loss ratio which implies that premium grows faster than claims inflation and possibly there is value adjustment in insurance consumption in times of inflation with concomitant increase in claims. On interest rates, it suggests possibility of cash flow underwriting may occur through rate-cutting and high risk taking in periods of high interest rate resulting in higher volume of premium. Furthermore, rates are regulated in the non-life sector in Nigeria, therefore systematic price discounting is less relevant and unethical rate-cutting may be quite prevalent in times of high interest rate giving a positive shock to loss ratio.

However, there is strong evidence that premium growth rate is adversely affected by inflation rate for long periods but less significantly to shocks from interest rates. This could arise from sharp reduction in purchasing power while possible cash flow underwriting is really non-existent in periods of high interest rate; more so that pricing is fixed by tariff. It is of note that premium growth is not influenced by real economic growth which is fundamental departure to most studies. This underscores the low insurance penetration in the Nigerian non-life sector despite economic growth in the prevailing period. Previous premium has no influence on future performance

The overall implication is that the industry competes more on premium rate -cutting during periods of high interest income while loss distributions respond less to inflationary shocks through claims inflation. Altogether, this suggests poor underwriting strategies during these periods because insurance consumption is shocked by inflation risk and less affected by interest rate suggesting weak investment strategies. Also, it is quite revealing and surprising that historical premium growth rate had no shocking influence on future growth rate unlike other developed economies (Jawadi, Bruneau \& Sghaier, 2009) which may also attest to poor salesmanship and underwriting strategy. Much more surprising is 
that GDP growth rate does not influence premium growth rate as found in research. This may be attributable to possible non-transmission of economic growth to income of the people. This calls for greater research for developing economies.

The Nigeria insurance industry has huge growth potentials but is subject to performance shocks from macroeconomic risks that veer away from theoretical underpinnings as evidenced in this study. In consequence, the policy makers should consider that the performance of the insurance sector to grow premiums and reduce loss ratios depends on the active management of interest and inflation rates since they adversely affect the underwriting performance. Very surprisingly, real GDP growth rate has not influenced the growth and performance of the industry. The government has to devise an economic blueprint to increase the level of per capita income, reduce dependency ratio and income inequality to connect GDP growth to the insurance industry. The regulators should consider rate deregulation in the non-life sector to enable proper pricing which may possibly incentivize increased demand of insurance through competitive underwriting strategy. Nigerian insurance companies should proactively develop products that can compete on managing claims using innovative underwriting strategy since loss ratio and premium growth are quite vulnerable to macroeconomic shocks in Nigeria.

\section{REFERENCES}

Agiobenebo, T.J. \& Ezirim, B.C. (2002). Impact of financial intermediation on the profitability of insurance companies in Nigeria. First Bank of Nigeria Quarterly Review, 2 (1), 4-14

Ahmed, I. (2016). Effect of capital size on the profitability of listed insurance firms in Nigeria. African Journal of Business Management, 10 (5), 109-113.

Algrim, K. \& D' Arcy, S.P. (2012). The Effect of Deflation or High inflation on the Insurance Industry, Sponsored by Casualty Actuarial Society, Canadian Institute of Actuaries and Society of Actuaries.

Arneric, P. \& Curak. (2013). The Persistence of Insurers Profitability. Croatian Operational Research Review (CRORR), 4

Athanasoglous, P.P., Brissimis, S.N. \& Delis, M.D. (2008). Bank-specific, industry-specific and macroeconomic determinants of bank profitability. Journal of International Financial Markets, Institutions and Money, 18 (2), 121-136.

Ayele, A.G. (2012). Factors Affecting Profitability of Insurance Companies in Ethiopia: Panel Evidence (Doctoral dissertation, Addis Ababa University). Retrieved from http://etd.aau.edu.et/dspace/bitstream/ $123456789 / 4326$ accessed on March $2^{\text {nd }}, 2017$

Baluch, F., Mutenga, S. \& Parsons, C. (2011). Insurance, systemic risk and the financial crisis insurance. The Geneva Papers on Risk and Insurance. Issues and Practice, 36 (1), 126-163.

Bates, I. \& Atkins, D. (2007). Management of Insurance Operations. London, Global Professional Publishing.

Berger. A.N., Cummins, J.D. \& Weiss, M.A. (1997). The coexistence of multiple distribution systems for financial services: The case of property-casualty insurance. Journal of Business, 70 (4), 515-46.

Brainard, L. \& Schwartz, B.L. (2008). What is the role of insurance in economic development? Zurich, Zurich Government and Industry Affairs. Retrieved from: www.zurich.com/internet/main/sitecollectiondocuments/ insight/what_is_the_role_of_economic_development.pdf Accessed on $15^{\text {th }}$ June 2016

Brigham, E.F. \& Ehrhardt, M.C. (2014). Financial management: Theory and practice, USA, South Western Cengage Learning

Brown, M.J., Chung, J. \& Frees, E.W. (2000). International property-liability insurance consumption. Journal of Risk and Insurance, 67 (1), 73-90.

Browne M.J. \& Kamiya, S. (2012). A Theory of the Demand for Underwriting. The Journal of Risk and Insurance, 79 (2) 335-349.

Central Bank of Nigeria (2015). Statistical Bulletin. Abuja, Nigeria

Chang, C.H. \& Lee, C.C. (2012). Non-Linearity Between Life Insurance and Economic Development: A Revisited Approach. The Geneva Risk and Insurance Review, 37 (2), 223-257. 
Charumathi, B. (2012). On the determinants of profitability of Indian life insurers - An empirical study. Proceedings of the World Congress on Engineering. London, U.K, I WCE.

Chen, T.J. \& Huang, M.H. (2001). An empirical analysis of determinants of cash holdings by insurance companies in Taiwan. Insurance Monograph, 66, 1-26.

Chen, Y. \& Hamwi, I.S. (2000). Performance analyses of U.S. Property-Liability Reinsurance Companies. Journal of Insurance Issues, 23 (2), 140-152.

Chidambaran, N.K., Pugel T.A. \& Saunders, A. (1997). An investigation of the performance of the U.S. property-liability insurance industry. Symposium on Financial Risk Management in Insurance Firms. The Journal of Risk and Insurance, 64 (2), 371-382.

Choi, B.P. (2010). The U.S. property and liability insurance industry: Firm growth, size, and age. Risk Management and Insurance Review, 13 (2), 207-224.

Cummins, J.D. (1991). Statistical and Financial Models of Insurance Pricing and the Insurance Firm. The Journal of Risk and Insurance, 58 (2), 261-302.

Curak, M., Pepur, S. \& Poposki, K. (2011). Firm and Economic Factors and Performance: Croatian Composite Insurers. The Business Review Cambridge, 19 (1), 136-142.

D'Arcy, S.P. (1988). Use of the CAPM to Discount Property-Liability Loss Reserves. The Journal of Risk and Insurance, 55, 481-491.

Datu, N. (2016). How do insurer specific indicators and macroeconomic factors affect the profitability of insurance business? A panel data analysis on the Philippine Non-life Insurance market, DLSU Research Congress. De La Salle University, Manila, Philippines.

Doherty, N.A. \& Garven, J. R. (1995). Insurance cycles: Interest rates and the capacity constraints model. The Journal of Business, 68 (3), 383-404.

Fairley, W.B. (1979). Investment income and profit margins in property-liability insurance: Theory and empirical results. Bell Journal of Economics, 10, 192-210.

Fischer, I. (1971). The purchasing Power of Money, New York, Augustus M. Kelly, Reprints of Economic Classics

Goddard, J., Liu, H., Molyneux, P. \& Wilson, O.S.J. (2011).The persistence of bank profit. Journal of Banking and Finance, 35 (11), 2881-90.

Han, L., Li, D., Moshirian, F. \& Tian, Y. (2010). Insurance Development and Economic Growth. The Geneva Papers on Risk and Insurance. Issues and Practice, 35 (2), 183-199.

Hardwick, P. \& Adams, M. (2002). Firm size and growth in the United Kingdom life insurance industry. The Journal of Risk and Insurance, 69 (4), 577-593.

Ito, K. \& Fukao, K. (2010). Determinants of the profitability of Japanese manufacturing affiliates in China and other regions: Does localisation of procurement, sales and management matter?. World Economy, 33 (12), $1639-71$.

Jawadi, F. Bruneau, C. \& Sghaier, N. (2009). Nonlinear cointegration relationships between Non-life insurance premiums and financial markets. The Journal of Risk and Insurance, 76 (3), 753-783.

Kaplan, M. \& Çelik, T. (2008). The persistence of profitability and competition in the Turkish banking sector. 157-167. Retrieved from: http://iibf.erciyes.edu.tr/dergi/sayi30/mkaplan.pdf

Kohers T. \& Greene, M.R. (1977). Company size and financial performance: some evidence from the insurance industry. The Journal of Insurance Issues and Practices, 1 (3), 59-66.

Kozak S. (2011). Determinants of profitability of non-life insurance companies in Poland during integration with the European financial system. Electronic Journal of Polish Agricultural Universities, 14 (1), \#01.

Lee, C.Y. (2014). The Effects of Firm-Specific Factors and Macroeconomics on Profitability of PropertyLiability Insurance Industry in Taiwan. Asian Economic and Financial Review, 4 (5), 681-691.

Lee, C.C., Hsu, Y.C. \& Lee, C.C. (2010). An Empirical Analysis of Non-Life Insurance Consumption stationarity. The Geneva Papers on Risk and Insurance: Issues and practice, 35 (2), 266-289.

Levy, H. (2002). Fundamentals of Investments. Great Britain, Pearson Education Limited

Liedtke, P.K. (2007). What's Insurance to a Modern Economy?. The Geneva Papers on Risk and Insuranceissues and Practice, 32 (2), 211- 221.

Ma, Y.L. \& Pope, N. (2003). Determinants of International Insurers' Participation in Foreign Non-Life Markets. The Journal of Risk and insurance, 70 (2), 235-248.

Nigerian Insurers Association, (2011). Nigeria Insurance Digest. Victoria Island, Lagos, Nigerian insurance association

Nigerian Insurers Association, (2013). Nigeria Insurance Digest. Victoria Island, Lagos, Nigerian insurance association 
Nigerian Insurers Association, (2015). Nigeria Insurance Digest. Victoria Island, Lagos, Nigerian insurance association

Malik, H. (2011). Determinants of Insurance Company Profitability: An Analysis of Insurance Sector in Pakistan. Academic Research International, 1 (3), 315-321.

Myers, S.C. \& Cohn, R. A. (1987). A Discounted Cash Flow Approach to Property-Liability Insurance: Theory and Empirical Results. In Fair rate of Return in Property-Liability Insurance, edited by Cummins and Harrington. Boston: Kluwer

Nweke, M. (2017). Distress: 23 Insurance firms post losses. Retrieved from The Sun, www.sunnewsonline.com Accessed on: July $7^{\text {th }}, 2017$

Outreville, J.F. (2013). The relationship between insurance and economic development: 85 Empirical Papers for a Review of the Literature. Risk Management and Insurance Review, 16 (1), 71-122.

Outreville, J.F. (1990). The economic significance of insurance markets in developing countries. Journal of Risk and Insurance, 57 (3), 487-498.

Pervan, M., Arneric, J. \& Curak, M. (2013). The Persistence of Insurers Profitability. Croatia operational Business Review, 4, 132 -141.

Pervan, M. \& Pavić, K.T. (2010). Determinants of insurance companies' profitability in Croatia, The Business Review Cambridge, 16 (1), 231-238.

Seelanatha, L. (2011). Determinants of Firms' Performance: Some Chinese Evidence. Investment Management and Financial Innovations, 8 (3), 28-38.

Shiu, Y. (2004). Determinants of United Kingdom general insurance company performance. British Actuarial Journal, 10, 1079-1110.

Tosetti, A., Behar, T., Fromenteau, M. \& Menart, S. (2001). Insurance: Accounting, Regulation, Actuarial Science. The General Papers on Risk and Insurance Issues and Practice, 26 (2), 232-251.

Vejzagic, M. \& Zarafat, H. (2014). An analysis of macroeconomic determinants of commercial banks profitability in Malaysla for period 1995-2011. Asian Economic and Financial Review, 4 (1), 41-57.

Ward, D. \& Zurbruegg, R. (2000). Does insurance promote economic growth? Evidence from OECD countries. Journal of Risk and Insurance, 489-506.

Williams, B. (2003). Domestic and International Determinants of Bank Profits: foreign Banks in Australia. Journal of Banking and Finance, 27 (6), 1185-1210.

Weiss, M.A. (2007). Underwriting cycles: A synthesis and further directions. Journal of Risk and Insurance, 30 (1), $31-45$.

Wen, M.M. \& Born, P. (2005). Firm-Level data analysis of the effects of net investment income on underwriting cycles: An application of simultaneous equations. Journal of Insurance Issues, 28 (1), 14-32.

Whittington, G. (1980). The profitability and size of United Kingdom Companies 1960- 74. The Journal of Industrial Economics, 28, 335-35.

World Bank (2003), Nigeria Policy Options for Growth and Stability, Report No. 26215-NGA, Washington DC: The World Bank.

\section{UTICAJ NAGLIH PROMENA NA POSLOVANJE OSIGURAVAJUĆIH DRUŠTAVA IZ SEKTORA NEŽIVOTNOG OSIGURANJA U NIGERIJI I MAKROEKONOMSKI RIZICI - VEKTORSKI AUTOREGRESIONI PRISTUP}

Poslovanje osiguravajućeg društva može biti otežano internim i eksternim rizicima. Izveštaji pokazuju da su 23 od 55 kompanija koje posluju u Nigeriji (oko 42\%) zabeležile neto operativne gubitke u 2015. godini. Makroekonomski rizici su eksterni i mogu biti veoma značajni u obezbeđivanju (ne)povoljnog okruženja za razvoj industrije, posebno u ekonomija kao što je Nigerija. Kada se ima u vidu doprinos osiguranja nigerijskoj ekonomiji, koje pokazuje neuobičajeno nisku penetraciju, prosečno ispod jednog procenta BDP-a, u poređenju sa afričkim državama kao što su Južnoafrička republika sa $13 \%$ i Kenija iznad dva procenta; od suštinske je važnosti istražiti kako ovi rizici mogu uticati na prodor osiguranja. Dinamička regresija najmanjih kvadrata je korišćena za proučavanje dinamike makroekonomskih rizika (BDP, stopa inflacije i kamatne stope) na rezultate poslovanja osiguravajućih društava u periodu 1981-2015. U odnosu na teorijske osnove $i$ druge studije naročito u zapadnim 
ekonomijama, studija ima dokaze da nagle promene u stopi kamate i inflacije negativno utiču na poslovanje osiguravajućeg društva. Takođe, realni BDP nema pozitivan uticaj na rast premija i racio steta. Monetarna politika bi trebalo da se bavi inflacijom i kamatnim stopama kako bi se u Nigeriji ublažili šokovi u poslovanju osiguravajućih društava u sektoru neživotnog osiguranja. Dugoročno, vlada bi trebalo da se fokusira na povećanje dohotka po glavi stanovnika i smanjenje nejednakosti dohotka i racia zavisnosti kako bi se potrošnja osiguranja povezala sa realnim rastom BDP-a.

Ključne reči: Makroekonomski rizici, nagle promene u osiguranju, profitabilnost 